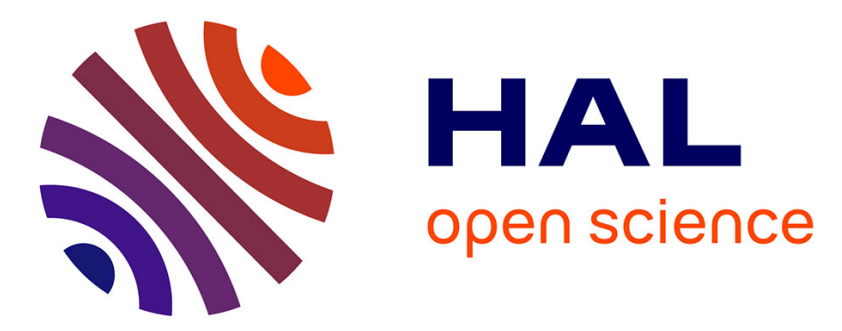

\title{
Nivolumab-refractory patients with advanced non-small-cell lung cancer
}

\author{
A. Costantini, V. Fallet, J. Corny, S. Friard, C. Chouaid, B. Duchemann, E. \\ Giroux-Leprieur, L. Taillade, L. Doucet, S. Brosseau, et al.
}

\section{To cite this version:}

A. Costantini, V. Fallet, J. Corny, S. Friard, C. Chouaid, et al.. Nivolumab-refractory patients with advanced non-small-cell lung cancer. Lung Cancer, 2019, 130, pp.128-134. 10.1016/j.lungcan.2019.01.015 . hal-02321317

\section{HAL Id: hal-02321317 https://hal.sorbonne-universite.fr/hal-02321317}

Submitted on 21 Oct 2019

HAL is a multi-disciplinary open access archive for the deposit and dissemination of scientific research documents, whether they are published or not. The documents may come from teaching and research institutions in France or abroad, or from public or private research centers.
L'archive ouverte pluridisciplinaire HAL, est destinée au dépôt et à la diffusion de documents scientifiques de niveau recherche, publiés ou non, émanant des établissements d'enseignement et de recherche français ou étrangers, des laboratoires publics ou privés. 


\section{Accepted Manuscript}

Title: Nivolumab-refractory patients with advanced non-small-cell lung cancer

Authors: A. Costantini, V. Fallet, J. Corny, S. Friard, C.

Chouaid, B. Duchemann, E. Giroux-Leprieur, L. Taillade, L.

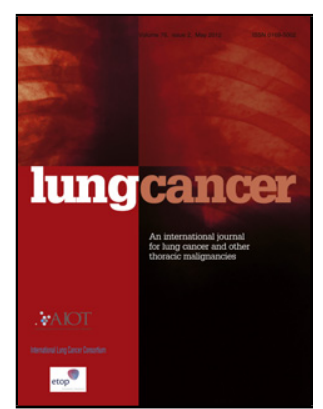

Doucet, S. Brosseau, M. Wislez, J. Tredaniel, J. Cadranel

PII:

S0169-5002(19)30301-0

DOI: https://doi.org/10.1016/j.lungcan.2019.01.015

Reference: LUNG 5912

To appear in:

Lung Cancer

Received date:

7 October 2018

Revised date:

23 January 2019

Accepted date:

28 January 2019

Please cite this article as: Costantini A, Fallet V, Corny J, Friard S, Chouaid C, Duchemann B, Giroux-Leprieur E, Taillade L, Doucet L, Brosseau S, Wislez M, Tredaniel J, Cadranel J, Nivolumab-refractory patients with advanced non-small-cell lung cancer, Lung Cancer (2019), https://doi.org/10.1016/j.lungcan.2019.01.015

This is a PDF file of an unedited manuscript that has been accepted for publication. As a service to our customers we are providing this early version of the manuscript. The manuscript will undergo copyediting, typesetting, and review of the resulting proof before it is published in its final form. Please note that during the production process errors may be discovered which could affect the content, and all legal disclaimers that apply to the journal pertain. 


\section{Nivolumab-refractory patients with advanced non-small-cell lung cancer}

A. Costantini $^{a}$, V. Falleta, J. Corny ${ }^{b}$, S. Friardc, C. Chouaidd, B. Duchemanne, E. Giroux-Leprieurf, L. Taillades, L. Doucet ${ }^{\mathrm{h}}$, S. Brosseau', M. Wislez ${ }^{\mathrm{a}}$, J. Tredaniel $^{\mathrm{b}}$, J. Cadranela

aAP-HP, Hôpital Tenon et Sorbonne Université, 4 Rue de la Chine 75020, Paris, France

'bôpital Saint-Joseph,185 Rue Raymond Losserand 75014, Paris, France

'Hôpital Foch, 40 Rue Worth 92151, Suresnes, France

${ }^{d}$ Centre Hospitalier Intercommunal de Créteil, 40 Avenue de Verdun 94000, Créteil, France

eAP-HP, Hôpital Avicenne, 125 Rue de Stalingrad 93000, Bobigny, France)

†AP-HP, Hôpital Ambroise Pare, 9 Avenue Charles de Gaulle 92100, BoulogneBillancourt, France

9AP-HP, Hôpital Pitié-Salpêtrière, 47-83 Boulevard de l'hôpital 75013, Paris, France

hAP-HP, Hôpital Saint-Louis, 1 Avenue Claude Vellefaux 75010, Paris, France

'AP-HP, Hôpital Bichat, 46 Rue Henri Huchard 75018, Paris, France

Corresponding author: Jacques Cadranel, Hôpital Tenon, 4 Rue de la Chine 75020,

Paris, France. jacques.cadranel@aphp.fr

\section{Highlights}

- Hyper progressive disease is a new form of progression in patients treated with immunotherapy

- The definition of HPD is yet to be consensual

- We suggest a clinical definition of patients refractory to immunotherapy based on the number of nivolumab injections 
- $20 \%$ of patients with advanced NSCLC presented with nivolumab refractory disease in our real-life cohort

- Factors associated with refractory disease were $\mathrm{PS} \geq 2$, shorter duration of treatment before nivolumab initiation

\section{$\underline{\text { Structured abstract }}$}

Introduction: Immune checkpoint inhibitors (ICls) have revolutionised cancer care especially in lung cancer. New response patterns have been described under ICIs such as pseudo-progression or hyper-progressive disease (HPD). The definition of HPD is yet to be consensual. The aim of this study was to suggest a clinical definition of nivolumab-refractory patients and find factors associated with this entity.

Methods: We performed a multi centric retrospective study including all patients who received nivolumab for the treatment of advanced non-small cell lung cancer (NSCLC) during the French authorisation for temporary use in 2015.

Results: 303 patients were included in the cohort and 292 had details on the number of nivolumab injections received. 57 patients (20\%) were nivolumab-refractory. These patients had worse PS at nivolumab initiation $(p<0.0001)$, shorter duration of treatment before nivolumab $(p=0.028)$ and had dramatically shorter nivolumab overall survival $(p<0.0001)$ than patients who did not present with refractory disease.

Conclusion: Nivolumab-refractory disease can affect up to $20 \%$ of patients treated with nivolumab for advanced NSCLC with dramatically shortened survival rates. Further studies are needed to understand the precise mechanisms leading to refractory disease as well as its management. 


\section{$\underline{\text { Key words }}$}

nivolumab, non-small-cell lung cancer, treatment, refractory 


\section{Introduction}

Nivolumab is a fully human IgG4 programmed death 1 (PD-1) immune checkpoint inhibitor (ICI) antibody that disrupts PD-1 mediated signalling. Nivolumab is authorised in the second line setting for the treatment of advanced non-small cell lung cancer (NSCLC) for both squamous and non-squamous histology in patients having progressed during or after a first line of treatment associating a platinum-based doublet chemotherapy (CT) regimen and now represents the gold standard for second line treatment [1,2] along with atezolizumab, which is also registered in this setting, [3] and pembrolizumab for patients with PD-L1 tumour expression of more than $1 \%$ as measured by IHC [4]. Recently, ICls have soared to the forefront of cancer treatment, especially in advanced NSCLC with studies testing first-line pembrolizumab in patients with high expression of PD-L1 on tumour cells ( $\geq 50 \%)$ [5]. First line pembrolizumab or atezolizumab associated with platinum-doublet CT $[6,7]$ have also been evaluated. Finally, first-line nivolumab ipilimumab association has also been tested [8].

Different progression patterns have been described with ICls prompting the creation of a new RECIST evaluation method [9]. The usual progression criteria have been modified with new paradigms being introduced such as pseudo-progression. Another form of progression described as hyper-progressive disease (HPD) has recently been reported [10, 11, 12]. However, HPD is yet to be precisely defined. One approach measures Tumour Growth Rate (TGR) [10] or Tumour Growth Kinetics (TGK) [11]. Although precise, this method requires multiple CT-scans to be performed, at baseline and during $\mathrm{ICI}$ treatment, and will be inappropriate for ICls delivered in the first line setting. Furthermore, specialised radiologists must measure the TGR/TGK to confirm HPD. Another study analysed early-death in Japanese patients with NSCLC treated with nivolumab [13]. Early death was defined as death occurring within three months of initiating nivolumab which exposes to bias and confounding factors, such as death from other causes or usual early progression that occurs in more than $50 \%$ of cases in non-selected patients treated by nivolumab and atezolizumab in the second line setting $[1,2,3]$. 
In this context, we aimed to identify factors associated with poor prognosis under nivolumab and thus defining a group of patients who are refractory to immunotherapy. This analysis was performed in a large retrospective real-life cohort of patients with advanced NSCLC treated with nivolumab.

\section{Materials and methods}

\section{Study population}

We performed a multicentre retrospective study in nine thoracic oncology centres. We included all consecutive patients that had received at least one injection of nivolumab for the treatment of NSCLC in 2015. The patients all received nivolumab (3mg/kg every 15 days) during the French authorisation for temporary use (ATU) between the $1^{\text {st }}$ of January 2015 and the $31^{\text {st }}$ of December 2015. The cut-off date was the $31 / 12 / 2016$. Patients were censored at this date with status registered.

\section{$\underline{\text { Radiological assesment }}$}

Response to treatment was evaluated using CT-imaging usually consisting of at least thoracic and brain imaging. Due to the retrospective nature of this study and the fact that patients were not included in clinical trials, there was no standardised interval to re-evaluate disease. CT was performed at clinicians' discretion, however, it was usually performed after 3 or 4 infusions of nivolumab ( 6 to 8 weeks after nivolumab initiation) but it could also be performed earlier, often in case of worsening or new symptoms. Disease was evaluated using the RECIST v1.1 criteria and treatment decisions were discussed during multidisciplinary meetings.

\section{$\underline{\text { Data collection }}$}


Medical records were reviewed, and data extracted on clinical and pathological features, as well as treatment history. Nivolumab OS (NivoOS) was measured from initiation of nivolumab (date of first injection) to death. Nivolumab. PFS (NivoPFS) was measured from initiation of nivolumab (date of first injection) to progressive disease according to RECIST v1.1 criteria or death. In all cases, if death had not occurred on the $31 / 12 / 2016$, patients were censored at this date. Patients lost during follow-up were censored on the date of last follow-up.

\section{Defining the refractory population}

To help define a population of nivolumab-refractory patients, we drew the distribution histogram of the number of nivolumab injections administered to each patient (Figure 1). The distribution was at least bi-modal: one usual population where patients progressed after three or four injections and then regularly through time (green square), and a second population where patients seemed to experience unusually rapid progression (red square), before the evaluation time recommended in clinical trials $[1,2,3,4.5,6,7,8]$. Amongst the selected patients, those who stopped nivolumab due to toxicity were excluded from the analysis.

\section{Statistical analysis}

The study population was separated into two groups: one group represented the nivolumab-refractory population and the other the non-refractory population. In order to find factors associated with refractory disease, the characteristics of the two groups were compared using Chi-squared and Fisher's tests for categorical variables and ttests and Mann-Whitney tests for continuous variables according to their distribution. The Kaplan-Meier method was used to estimate OS. 
Data analysis was performed using XLSTAT version 19.4 (Addinsoft, Bordeaux, France).

\section{Ethical considerations}

Participating centres were responsible for patient consent and institutional approval. All contributors were trained in good clinical practice. The study was purely an academic collaboration and was not funded by industry.

\section{Results}

Median follow-up after nivolumab initiation was 14.8 months [95\% $\mathrm{Cl}(13.9-15.7)]$.

\section{$\underline{\text { Patients }}$}

We had at our disposal a cohort of 303 patients who had received nivolumab in 2015 for the treatment of advanced NSCLC. We were able to include 292 patients (96\%) for which we had the detail concerning the number of nivolumab injections received.

\section{Characteristics of the global population}

Table 1 summarises the baseline clinical and pathological characteristics of the 303 patients: $69 \%$ were male, $92 \%$ were current or former smokers with adenocarcinoma histology in $61 \%$ and squamous cell carcinoma in $28 \%$ of cases, respectively. Molecular analysis testing for Epidermal Growth Factor Receptor (EGFR) mutation, KRAS mutation, Anaplastic Lymphoma Kinase (ALK) translocation and BRAF mutation 
showed that only 10 patients (3\%) had EGFR mutation, 50 patients (17\%) had KRAS mutation and that 219 (72\%) were wild-type for EGFR, KRAS, BRAF and ALK.

Median (range) age at diagnosis was $63(12-91)$ years and median age at nivolumab initiation was $65(17-91)$ years. The most frequent extra-thoracic metastatic sites at nivolumab initiation were the bone (26\%) and the central nervous system (CNS) $(20 \%)$; 102 (34\%) had abdominal metastases (liver and adrenal glands). Patients received second line nivolumab in $40 \%$ of cases and had low PS $(0-1)$ in $67 \%$ of cases. The median number of nivolumab injections was $6(1-43)$.

Median NivoOS was 11.3 months [95\% Cl $(8.5-13.6)]$ and median NivoPFS was 2.6 months $[95 \% \mathrm{Cl}(2.1-3.5)]$.

\section{Early outcomes}

Fifty-eight patients (20\%) received less than three injections of nivolumab. One patient stopped nivolumab because of toxicity and was excluded from the analysis. Thus, fittyseven patients $(20 \%)$ were included in the nivolumab-refractory population comprised of 16 patients (28\%) who stopped nivolumab because of disease progression, 36 patients $(63 \%)$ who stopped nivolumab because of death and five patients $(9 \%)$ who were lost during follow-up and censored

Two hundred and thirty-four patients (80\%) received three or more injections of nivolumab. Six patients stopped nivolumab due to toxicity and did not present with progression during the follow-up period. They were excluded from the analysis. Two hundred and twenty-eight patients $(78 \%)$ were included in the non-refractory population comprised of 159 patients (70\%) who stopped nivolumab because of disease progression, 13 patients (6\%) who stopped nivolumab because of death, six patients $(2 \%)$ who stopped nivolumab for other reasons, two patients $(1 \%)$ who were lost during follow-up and 37 patients (16\%) who were censored at cut-off date 


\section{$\underline{\text { Characteristics of the nivolumab-refractory patients }}$}

The $57(20 \%)$ nivolumab-refractory patients had the following characteristics that did not differ from the rest of the population (Table 2): $68 \%$ were male, $89 \%$ were current or former smokers with adenocarcinoma histology in $60 \%$ and squamous cell carcinoma in $24 \%$ of cases, respectively. Median age at diagnosis was 64 years and median age at nivolumab initiation was 65 years. However, when comparing the baseline clinical characteristics of our predefined groups (Table 2) we found that nivolumab-refractory patients had shorter treatment duration before receiving nivolumab $(p=0.013)$. Twenty patients $(35 \%)$ received second line nivolumab in the refractory group compared to $90(39 \%)$ in the non-refractory group $(p=0.98)$. We also found that patients who would later present with refractory disease had worse PS at nivolumab initiation (PS $0-1: 42 \%$ vs $73 \% ; p<0.0001$ ). Finally, we found that patients presenting with refractory disease had more bone metastasis at nivolumab initiation $(n=22,39 \%)$ compared to non-refractory patients $(n=53,23 \%)(p=0.063)$ although the difference was not statistically significant.

\section{Survival in nivolumab-refractory patients}

Patients who presented with refractory disease had shorter NivoOS than patients who did not: NivoOS was 1.4 months $[95 \% \mathrm{Cl}(1.1-1.8)]$ in the refractory group and 13.5 months $[95 \% \mathrm{Cl}(11.1-15.1)](p<0.0001)$ in the non-refractory group. In this context, we found that patients who presented with refractory disease had a lower tendency of receiving further treatment after nivolumab progression $(n=5,9 \%)$ compared to patients who did not present with refractory disease $(n=107,47 \%)(p<0.0001)$. 
Efficacy of treatment after nivolumab failure in the refractory population

Only five patients $(9 \%)$ of the refractory group received CT after nivolumab progression. The different treatments received as well as survival times are shown in table below.

\begin{tabular}{|c|c|c|c|c|}
\hline Patients & Drug & $\begin{array}{ll}\begin{array}{l}\text { Median } \\
\text { (months) }\end{array} & \text { PFS }\end{array}$ & $\begin{array}{ll}\begin{array}{l}\text { Median } \\
\text { (months) }\end{array} & \text { OS } \\
\end{array}$ & Further treatment \\
\hline Patient 1 & Docetaxel & 0.56 & 0.56 & No \\
\hline Patient 2 & Gemcitabine & 2.20 & 2.20 & No \\
\hline Patient 3 & Paclitaxel & 9.34 & 10.39 & No \\
\hline Patient 4 & Afatinib & 1.97 & 1.97 & No \\
\hline Patient 5 & $\begin{array}{l}\text { Paclitaxel } \\
\text { Bevacizumab }\end{array}$ & 3.02 & 6.10 & Yes, Erlotinib \\
\hline
\end{tabular}

Two-patients seem to truly benefit from salvage CT whereas the others have poor survival times.

\section{Discussion}

\section{Defining nivolumab-refractory patients}

Anticipating response to, and benefit from immunotherapy is a major challenge. As has been shown, some patients experience HPD (Table 3), defined by TGR or TGK. These methods, precise and objective have indeed helped to prove the existence of HPD in patients treated with ICls, but they require time, skilled radiologists and seem difficult to implement into daily clinical practice especially as ICls will soon be moved up to the first line setting. Other studies have evaluated early death, this definition exposes to bias as it also includes patients who will die from other factors such as immune related 
adverse events, infectious causes or other comorbidities. We defined a population of patients as nivolumab-refractory if they presented with progressive disease or death occurring before they received 3 injections of nivolumab, as suggested by the review of the proportion of patients receiving an increasing number of nivolumab injections. Even if this definition might also suffer from the same biases as the previous one, it has the advantage of being easy to use and reproducible.

\section{Frequency of nivolumab-refractory patients}

We report that up to $20 \%$ of patients suffering from NSCLC received less than three injections of nivolumab, close to what has been reported in early death (18.9\%). In previous studies, HPD has been reported from 9\% [10] to 29\% [11] of patients receiving ICls. In the first study, however, the analysis was performed exclusively in patients included in phase I clinical trials and 21 different cancer locations were reported [10]. This represents an extremely selected and yet very heterogeneous population of patients with good PS which could explain why the frequency of HPD might have been underestimated.

\section{$\underline{\text { Age and PS at nivolumab initiation }}$}

It has previously been reported [10] that age is correlated with HPD: older patients seem to benefit less from immunotherapy than younger patients. We did not find that age was associated with being refractory to immunotherapy in our large cohort of patients suffering from NSCLC, when comparing age at nivolumab initiation between our two groups we did not find a statistically significant difference $(p=0.53)$.

Our population of patients is representative of the population of lung cancer patients encountered outside of clinical trials. Based on our results, it seems difficult to deny immunotherapy to older patients on the sole basis of age. 
We found that PS at nivolumab initiation was associated with worse outcomes (Figure 2). When comparing PS at nivolumab initiation between patients having received $\leq 2$ and $>2$ injections, we found a statistically significant difference between the two $(p<0.0001)$. This finding has not been consistently reported but it underlines the importance of carefully evaluating patient fitness before prescribing ICls.

\section{Survival}

Survival in the overall population was in line with the results reported in the Checkmate studies [1, 2].

Early-death, i.e. death occurring within 3 months of nivolumab initiation [13] was reported in 70 patients (24\%) slightly higher than what has been reported previously. Patients who were refractory to nivolumab had shorter NivoOS than patients who did not: NivoOS was 1.4 months $[95 \% \mathrm{Cl}(1.1-1.8)]$ in the refractory group and 13.5 months $[95 \% \mathrm{Cl}(11.1-15.1)](p<0.0001)$ in the non-refractory group.

\section{$\underline{\text { Bone metastasis }}$}

We found that patients with bone metastasis at nivolumab initiation had a tendency to be refractory to nivolumab $(p=0.063)$. This finding has not been reported elsewhere. The bone presents with reduced immunoreactivity and has remarkably low $\mathrm{T}$-cell $(<5 \%$ of mononuclear cells) and NK cells (1-2\% of lymphocytes in the bone marrow) proportions. This results in a small pool of effective cytotoxic cells and a large proportion of immature and suppressor immune cell types [14].

Furthermore, bone cells contribute to micro-environment immunosuppression by the secretion of immunosuppressive cytokines such as TGF-beta which represses the production of effector molecules (perforin, granzymes, Fas-ligand and interferon 
gamma). The bone and its micro-environment are in an immunosuppressed state and due to the low quality of blood vessels, T-cells are unable to reach and proliferate in the micro-environment. Patients with bone metastasis before initiation of immunotherapy have a pool of protected tumour cells

Patients who have a non-immunosensitive tumour would have been more prone to develop bone metastasis, an area of low immunogenicity. Thus, after $\mathrm{ICI}$ initiation these patients would present with rapid tumour progression. On the other hand, patients with immune controlled tumours would not have suffered metastatic spread, and the initiation of ICls would in fact be beneficial, placing them in the non-refractory group.

\section{Duration of treatment before immunotherapy}

We found that patients with refractory disease had shorter duration of treatment before they received nivolumab. This can be explained by the fact that patients with aggressive tumours with poor response to CT might also be expected to have poor response to ICls. This is interesting data as it would suggest that chemo-resistant tumours might also be immune-resistant.

Other factors: histology, metastatic sites, baseline steroids and antibiotics

As other studies have reported $[10,11,12,13]$, we did not find any difference in histological subtypes when comparing refractory and non-refractory patients.

Furthermore, corticosteroids have recently come under scrutiny [15] with a recent study showing that baseline use of steroids was associated with decreased overall response rate, progression free survival and overall survival. The impact of steroids was not analysed in our study, but they have not previously been associated with HPD. 
Finally, the use of antibiotics at baseline has never been evaluated and could be an interesting research direction.

\section{Number of metastatic sites}

We compared the number of metastatic sites (more than 2 and two or less) in patients refractory or not to nivolumab. We did not find a difference between the two groups $(p=0.36)$

\section{$\underline{\text { Patient management }}$}

In previous studies, the management of patients has not been evaluated and there is currently little data on what course of action to take when patients present with rapidly progressing or refractory disease.

When possible, repeat biopsy of a rapidly progressing site should be performed in order to gain insight into to the mechanism leading to hyper progression although tumour transformation or acquisition of molecular mutations do not seem to be the hallmark of immunotherapy resistance.

A case series [16] reports using high-dose corticosteroids and other symptomatic treatment (pleural tube placement) resulting in patient improvement. This was however as small case study ( 5 cases) without evaluation of TGR or TGK. Further studies with prospective date seem necessary.

The use of cytotoxic CT after immunotherapy progression has also been suggested $[16,17]$. Efficacy of CT after immunotherapy progression has been evaluated in retrospective studies with diverging results: some stating that response rates are higher [18, 19], others finding survival times close to what has been reported in historical studies [20]. 
This study brings new, yet limited data on the efficacy of salvage CT in a group of patients considered to be refractory to ICls. Only a small number of patients (9\%) were deemed eligible to further treatment and amongst these, the majority experienced continued disease progression and death. However, due to the absence of other alternatives, CT should be offered to these patients if the treating physician deems this as appropriate.

\section{$\underline{\text { Study limitations }}$}

The retrospective nature of our study implies certain limitations. Imaging was not centrally reviewed and although cases are usually reviewed during multi-disciplinary meetings, discrepancies can exist between the different study sites.

We analysed the location and number of metastatic sites before nivolumab initiation, however, this analysis would depend on the imaging modality used which was not standardly harmonised: PET-scanning could show metastatic sites not revealed by CTimaging as well as brain MRI is more sensitive than brain CT.

We chose to define refractory disease according to the number of nivolumab injections received. This was chosen as we did not have access to TGR or TGK. However, this choice can lead to bias as the number of injections is not necessarily associated with progression but also possibly other events such as toxicity which can cause delays. To limit this bias, patients who stopped nivolumab due to toxicity and who did not present with disease progression during follow-up were excluded.

Immunotherapy is a major breakthrough in the treatment of patients with NSCLC. Some patients do not respond to this time of treatment and experience HPD, early disease or are considered as refractory. Anticipating immune-escape is an ongoing 
process and although different factors have been identified they are not consistently found throughout different studies and the data available today is essentially retrospective. Table 3 shows the different factors associated with HPD, early death and refractory disease. Other studies have focused on biological factors such as Lung Immune Prognostic Index (LIPI) based on derived neutrophils/(leukocytes minus neutrophils) ratio and lactate deshydrogenase (LDH) levels [21]. An approach integrating clinical and biological factors in order to create a risk stratification could be useful. Patients at high risk of developing HPD or refractory disease would benefit from closer monitoring with more frequent clinical evaluations and earlier imaging which could be performed as soon as after the first injection of immunotherapy.

Prospective data is now needed to clearly identify which patients are at risk of not benefiting from immunotherapy. It does in fact seem difficult to deny this practice changing treatment on solely retrospective and sometimes diverging data.

For now, patients eligible to ICls should receive them according to international guidelines bearing in mind that a sub-group of patients will not benefit but might also experience worsening outcomes.

The next practice changing step seems to be the association of CT and immunotherapy. Evaluating the rate of HPD and refractory patients in this setting will be crucial. Perhaps the use of CT will help to minimise the negative effects of ICls such as toxicity and rapid progression.

\section{Conclusion}

ICls have transformed the landscape of lung cancer care. However, not all patients benefit from immunotherapy and recent studies have proven the existence of HPD, associated with worse outcomes. Few factors seem to be associated with HPD and measuring HPD requires multiple CT-scan in order to measure tumour growth, this is 
not currently accessible in routine practice and will have limitations in the first-line setting.

Our study brings new data with regards to factors associated with poor prognosis and we were able to define a population of patients, up to $20 \%$, who were refractory to nivolumab. They had worse PS at nivolumab initiation as well as shorter treatment duration prior to nivolumab initiation and shortened survival.

Anticipating poor response to ICls is crucial and early CT scanning after the second or even first injection of ICls could help, especially in patients with $P S \geq 2$.

Management of these patients relies on re-biopsy of a rapidly progressing site, interrupting immunotherapy and promptly initiating next-line treatment (cytotoxic CT) in case of maintained PS. The use of high-dose corticosteroids remains unclear. There is, however, still little data available to evaluate the efficacy of this strategy.

Further prospective studies are needed to help identify patients at risk of presenting poor outcomes with ICls and explore different treatment strategies. 


\section{$\underline{\text { References }}$}

1. Borghaei, H., Paz-Ares, L., Horn, L., Spigel, D.R., Steins, M., Ready, N.E., Chow, L.Q., Vokes, E.E., Felip, E., Holgado, E., Barlesi, F., Kohlhäufl, M., Arrieta, O., Burgio, M.A., Fayette, J., Lena, H., Poddubskaya, E., Gerber, D.E., Gettinger, S.N., Rudin, C.M., Rizvi, N., Crinò, L., Blumenschein, G.R., Antonia, S.J., Dorange, C., Harbison, C.T., Graf Finckenstein, F., Brahmer, J.R., 2015. Nivolumab versus Docetaxel in Advanced Nonsquamous Non-Small-Cell Lung Cancer. N. Engl. J. Med. 373, 1627-1639. https://doi.org/10.1056/NEJMoa1507643

2. Brahmer, J., Reckamp, K.L., Baas, P., Crinò, L., Eberhardt, W.E.E., Poddubskaya, E., Antonia, S., Pluzanski, A., Vokes, E.E., Holgado, E., Waterhouse, D., Ready, N., Gainor, J., Frontera, O.A., Havel, L., Steins, M., Garassino, M.C., Aerts, J.G., Domine, M., PazAres, L., Reck, M., Baudelet, C., Harbison, C.T., Lestini, B., Spigel, D.R., 2015. Nivolumab versus Docetaxel in Advanced Squamous-Cell Non-Small-Cell Lung Cancer. N. Engl. J. Med. 373, 123-135. https://doi.org/10.1056/NEJMoa1504627

3. Rittmeyer, A., Barlesi, F., Waterkamp, D., Park, K., Ciardiello, F., von Pawel, J., Gadgeel, S.M., Hida, T., Kowalski, D.M., Dols, M.C., Cortinovis, D.L., Leach, J., Polikoff, J., Barrios, C., Kabbinavar, F., Frontera, O.A., De Marinis, F., Turna, H., Lee, J.-S., Ballinger, M., Kowanetz, M., He, P., Chen, D.S., Sandler, A., Gandara, D.R., OAK Study Group, 2017. Atezolizumab versus docetaxel in patients with previously treated non-small-cell lung cancer (OAK): a phase 3, open-label, multicentre randomised controlled trial. Lancet Lond. Engl. 389, 255-265. https://doi.org/10.1016/S0140-6736(16)32517-X

4. Herbst, R.S., Baas, P., Kim, D.-W., Felip, E., Pérez-Gracia, J.L., Han, J.-Y., Molina, J., Kim, J.-H., Arvis, C.D., Ahn, M.-J., Majem, M., Fidler, M.J., Castro, G. de, Garrido, M., Lubiniecki, G.M., Shentu, Y., Im, E., Dolled-Filhart, M., Garon, E.B., 2016. Pembrolizumab versus docetaxel for previously treated, PD-L1-positive, advanced non-small-cell lung cancer (KEYNOTE-010): a randomised controlled trial. The Lancet 387, 1540-1550. https://doi.org/10.1016/S0140-6736(15)01281-7

5. Reck, M., Rodríguez-Abreu, D., Robinson, A.G., Hui, R., Csőszi, T., Fülöp, A., Gottfried, M., Peled, N., Tafreshi, A., Cuffe, S., O’Brien, M., Rao, S., Hotta, K., Leiby, M.A., Lubiniecki, G.M., Shentu, Y., Rangwala, R., Brahmer, J.R., KEYNOTE-024 Investigators, 2016. Pembrolizumab versus Chemotherapy for PD-L1-Positive Non-Small-Cell Lung Cancer. N. Engl. J. Med. 375, 1823-1833. https://doi.org/10.1056/NEJMoa1606774

6. Gandhi, L., Rodríguez-Abreu, D., Gadgeel, S., Esteban, E., Felip, E., De Angelis, F., Domine, M., Clingan, P., Hochmair, M.J., Powell, S.F., Cheng, S.Y.-S., Bischoff, H.G., Peled, N., Grossi, F., Jennens, R.R., Reck, M., Hui, R., Garon, E.B., Boyer, M., RubioViqueira, B., Novello, S., Kurata, T., Gray, J.E., Vida, J., Wei, Z., Yang, J., Raftopoulos, H., Pietanza, M.C., Garassino, M.C., KEYNOTE-189 Investigators, 2018. Pembrolizumab 
plus Chemotherapy in Metastatic Non-Small-Cell Lung Cancer. N. Engl. J. Med. 378, 2078-2092. https://doi.org/10.1056/NEJMoa1801005

7. Socinski, M.A., Jotte, R.M., Cappuzzo, F., Orlandi, F., Stroyakovskiy, D., Nogami, N., Rodríguez-Abreu, D., Moro-Sibilot, D., Thomas, C.A., Barlesi, F., Finley, G., Kelsch, C., Lee, A., Coleman, S., Deng, Y., Shen, Y., Kowanetz, M., Lopez-Chavez, A., Sandler, A., Reck, M., IMpower150 Study Group, 2018. Atezolizumab for First-Line Treatment of Metastatic Nonsquamous NSCLC. N. Engl. J. Med. 378, 2288-2301. https://doi.org/10.1056/NEJMoa1716948

8. Hellmann, M.D., Ciuleanu, T.-E., Pluzanski, A., Lee, J.S., Otterson, G.A., AudigierValette, C., Minenza, E., Linardou, H., Burgers, S., Salman, P., Borghaei, H., Ramalingam, S.S., Brahmer, J., Reck, M., O'Byrne, K.J., Geese, W.J., Green, G., Chang, H., Szustakowski, J., Bhagavatheeswaran, P., Healey, D., Fu, Y., Nathan, F., Paz-Ares, L., 2018. Nivolumab plus Ipilimumab in Lung Cancer with a High Tumor Mutational Burden. N. Engl. J. Med. 378, 2093-2104. https://doi.org/10.1056/NEJMoa1801946

9. Seymour, L., Bogaerts, J., Perrone, A., Ford, R., Schwartz, L.H., Mandrekar, S., Lin, N.U., Litière, S., Dancey, J., Chen, A., Hodi, F.S., Therasse, P., Hoekstra, O.S., Shankar, L.K., Wolchok, J.D., Ballinger, M., Caramella, C., de Vries, E.G.E., RECIST working group, 2017. iRECIST: guidelines for response criteria for use in trials testing immunotherapeutics. Lancet Oncol. 18, e143-e152. https://doi.org/10.1016/S1470$\underline{2045(17) 30074-8}$

10. Champiat, S., Dercle, L., Ammari, S., Massard, C., Hollebecque, A., Postel-Vinay, S., Chaput, N., Eggermont, A., Marabelle, A., Soria, J.-C., Ferté, C., 2017. Hyperprogressive Disease Is a New Pattern of Progression in Cancer Patients Treated by Anti-PD-1/PDL1. Clin. Cancer Res. Off. J. Am. Assoc. Cancer Res. 23, 1920-1928. https://doi.org/10.1158/1078-0432.CCR-16-1741

11. Saâda-Bouzid, E., Defaucheux, C., Karabajakian, A., Coloma, V.P., Servois, V., Paoletti, X., Even, C., Fayette, J., Guigay, J., Loirat, D., Peyrade, F., Alt, M., Gal, J., Le Tourneau, C., 2017. Hyperprogression during anti-PD-1/PD-L1 therapy in patients with recurrent and/or metastatic head and neck squamous cell carcinoma. Ann. Oncol. Off. J. Eur. Soc. Med. Oncol. 28, 1605-1611. https://doi.org/10.1093/annonc/mdx178

12. Ferrara, R., Mezquita, L., Texier, M., Lahmar, J., Audigier-Valette, C., Tessonnier, L., Mazieres, J., Zalcman, G., Brosseau, S., Le Moulec, S., Leroy, L., Duchemann, B., Lefebvre, C., Veillon, R., Westeel, V., Koscielny, S., Champiat, S., Ferté, C., Planchard, D., Remon, J., Boucher, M.-E., Gazzah, A., Adam, J., Bria, E., Tortora, G., Soria, J.-C., Besse, B., Caramella, C., 2018. Hyperprogressive Disease in Patients With Advanced Non-Small Cell Lung Cancer Treated With PD-1/PD-L1 Inhibitors or With Single-Agent Chemotherapy. JAMA Oncol. https://doi.org/10.1001/jamaoncol.2018.3676 
13. Inoue, T., Tamiya, M., Tamiya, A., Nakahama, K., Taniguchi, Y., Shiroyama, T., Isa, S.-I., Nishino, K., Kumagai, T., Kunimasa, K., Kimura, M., Suzuki, H., Hirashima, T., Atagi, S., Imamura, F., 2018. Analysis of Early Death in Japanese Patients With Advanced Nonsmall-cell Lung Cancer Treated With Nivolumab. Clin. Lung Cancer 19, e171-e176. https://doi.org/10.1016/i.cllc.2017.09.002

14. Baschuk N, Rautela J, Parker BS. Bone specific immunity and its impact on metastasis. Bonekey Rep. 2015 Apr 15;4:665. doi: 10.1038/bonekey.2015.32. eCollection 2015.

15. Arbour, K.C., Mezquita, L., Long, N., Rizvi, H., Auclin, E., Ni, A., Martínez-Bernal, G., Ferrara, R., Lai, W.V., Hendriks, L.E.L., Sabari, J.K., Caramella, C., Plodkowski, A.J., Halpenny, D., Chaft, J.E., Planchard, D., Riely, G.J., Besse, B., Hellmann, M.D., 2018. Impact of Baseline Steroids on Efficacy of Programmed Cell Death-1 and Programmed Death-Ligand 1 Blockade in Patients With Non-Small-Cell Lung Cancer. J. Clin. Oncol. Off. J. Am. Soc. Clin. Oncol. JCO2018790006. https://doi.org/10.1200/JCO.2018.79.0006

16. Kanazu M, Edahiro R, Krebe H, Nishida K, Ishijima M, Uenami T, Akazawa Y, Yano Y, Yamaguchi $T$, Mori M. Hyperprogressive disease in patients with non-small cell lung cancer treated with nivolumab: A case series. Thorac Cancer. 2018 Dec;9(12):1782-1787. doi: 10.1111/17597714.12894. Epub 2018 Oct 17.

17. Champiat S, Ferrara R, Massard C, Besse B, Marabelle A, Soria JC, Ferté C. Hyperprogressive disease: recognizing a novel pattern to improve patient management. Nat Rev Clin Oncol. 2018 Dec;15(12):748-762. doi: 10.1038/s41571-018-0111-2.

18. Park SE, Lee SH, Ahn JS, Ahn MJ, Park K, Sun JM. Increased Response Rates to Salvage Chemotherapy Administered after PD-1/PD-L1 Inhibitors in Patients with Non-Small Cell Lung Cancer. J Thorac Oncol. 2018 Jan;13(1):106-111. doi: 10.1016/j.jtho.2017.10.011. Epub 2017 Oct 31.

19. Schvartsman G, Peng SA, Bis G, Lee JJ, Benveniste MFK, Zhang J, Roarty EB, Lacerda L, Swisher $\mathrm{S}$, Heymach JV, Fossella FV, William WN Response rates to singleagent chemotherapy after exposure to immune checkpoint inhibitors in advanced nonsmall cell lung cancer. Lung Cancer. 2017 Oct;112:90-95. doi: 10.1016/j.lungcan.2017.07.034. Epub 2017 Aug 3.

20. Costantini A, Corny J, Fallet V, Renet S, Friard S, Chouaid C, Duchemann B, Giroux-Leprieur E, Taillade L, Doucet L, Nguenang M, Jouveshomme S, Wislez M, Tredaniel J, Cadranel J. Efficacy of next treatment received after nivolumab progression in patients with advanced nonsmall cell lung cancer. ERJ Open Res. 2018 Apr 20;4(2). pii: 00120-2017. doi: 10.1183/23120541.00120-2017. eCollection 2018 Apr.

21. Mezquita L, Auclin E, Ferrara R, Charrier M, Remon J, Planchard D, Ponce S, Ares LP, Leroy L, Audigier-Valette C, Felip E, Zerón-Medina J, Garrido P, Brosseau S, Zalcman G, Mazieres J, Caramela C, Lahmar J, Adam J, Chaput N, Soria JC, Besse B. Association of the Lung Immune Prognostic Index With Immune Checkpoint Inhibitor Outcomesin Patients 
With Advanced Non-Small Cell Lung Cancer. JAMA Oncol. 2018 Mar 1;4(3):351-357. doi: 10.1001/jamaoncol.2017.4771. 
Figure 1: Distribution histogram of the number of nivolumab injections administered to each patient

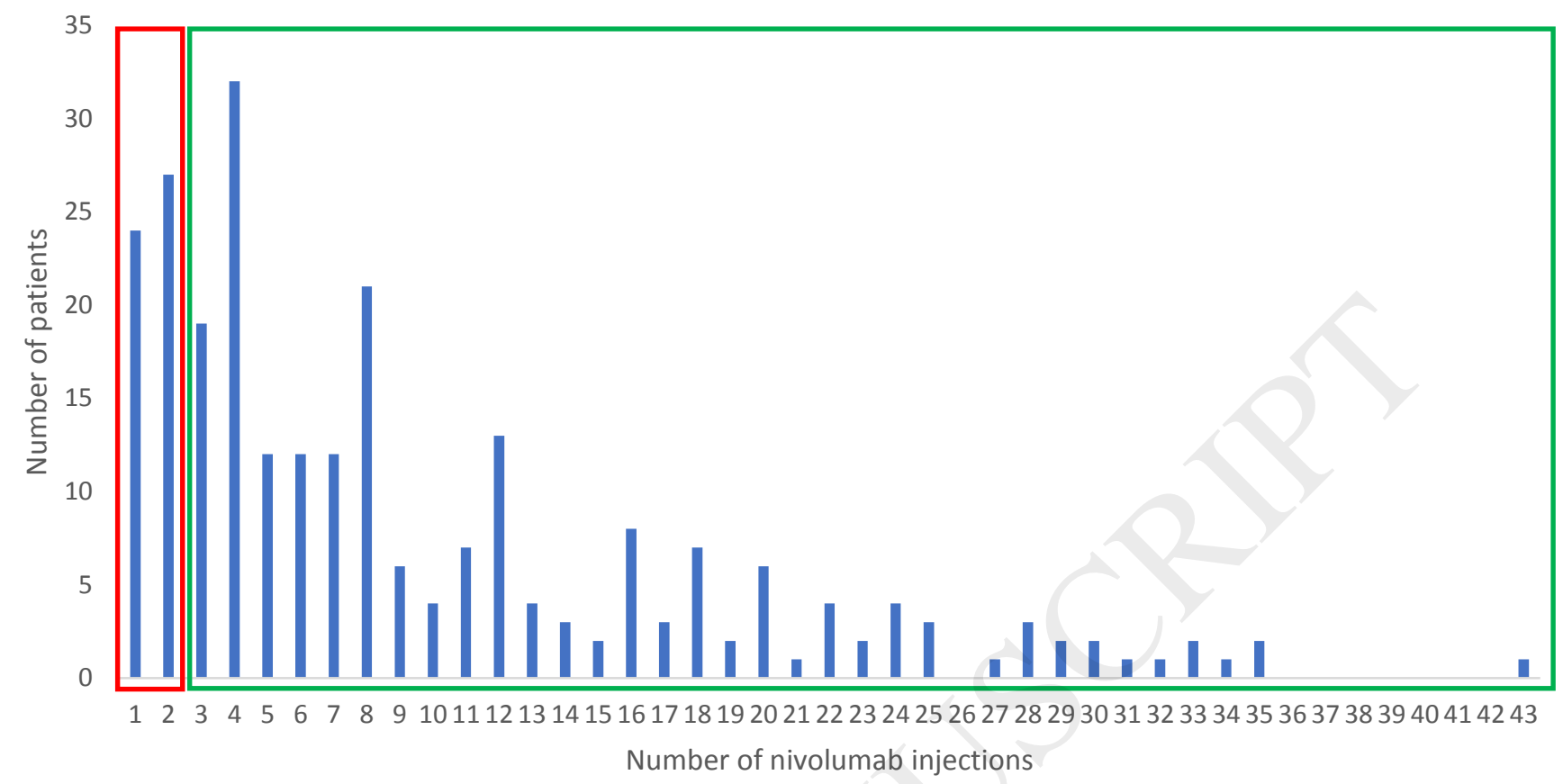

: nivolumab-refractory population

: non nivolumab-refractory population 
Figure 2: PS at nivolumab initiation in patients with and without refractory disease

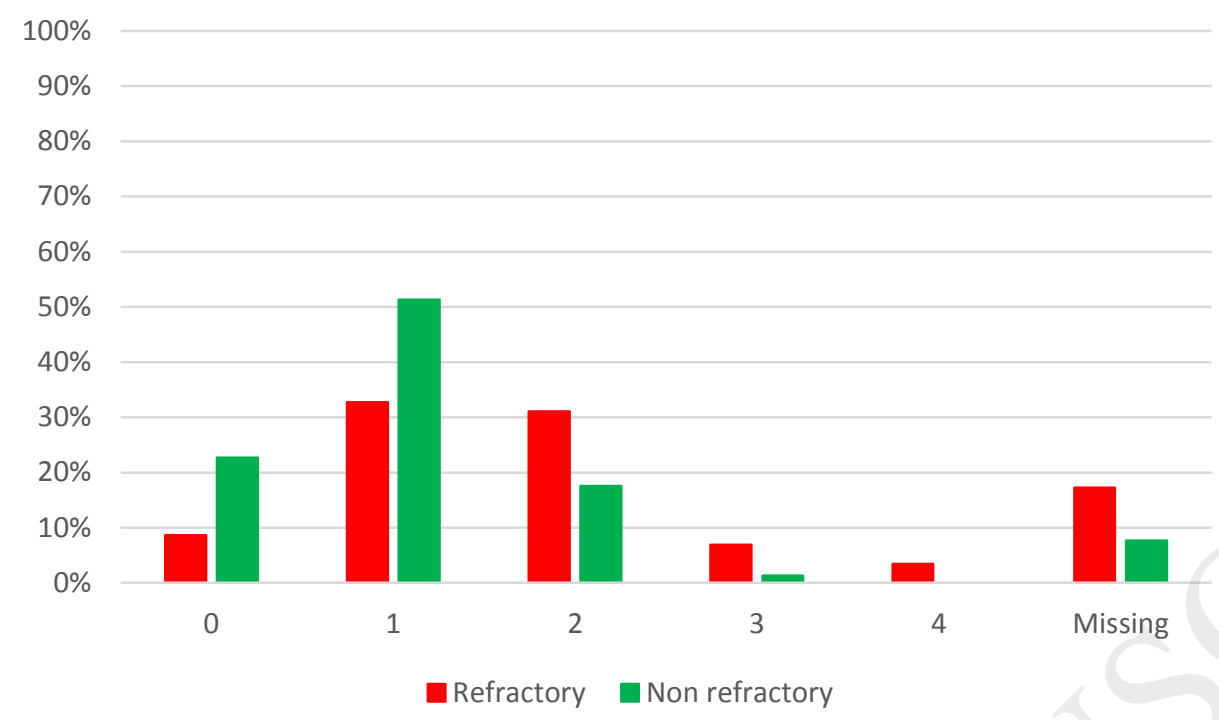


Table 1: clinical and pathological characteristics (all patients)

\begin{tabular}{|c|c|}
\hline Characteristics & All patients $(n=303)$ \\
\hline $\begin{array}{l}\text { Sex } n(\%) \\
\text { Male } \\
\text { Female }\end{array}$ & $\begin{array}{c}208(69 \%) \\
95(31 \%)\end{array}$ \\
\hline $\begin{array}{l}\text { Smoking history } \mathrm{n}(\%) \\
\text { Current or former } \\
\text { Never } \\
\text { Missing }\end{array}$ & $\begin{array}{l}278(92 \%) \\
23(8 \%) \\
2(1 \%)\end{array}$ \\
\hline $\begin{array}{l}\text { Histology on initial biopsy } \mathrm{n}(\%) \\
\text { Adenocarcinoma } \\
\text { Squamous cell carcinoma } \\
\text { Other }\end{array}$ & $\begin{array}{l}186(61 \%) \\
86(28 \%) \\
31(11 \%)\end{array}$ \\
\hline $\begin{array}{l}\text { Mutational status } n(\%) \\
\text { EGFR } \\
\text { KRAS } \\
\text { ALK } \\
\text { Other } \\
\text { Wild type }\end{array}$ & $\begin{array}{c}10(3 \%) \\
50(17 \%) \\
2(1 \%) \\
22(7 \%) \\
219(72 \%) \\
\end{array}$ \\
\hline Age at diagnosis, years (median, range) & $63,12-91$ \\
\hline $\begin{array}{l}\text { Age at nivolumab initiation, years (median, } \\
\text { range) }\end{array}$ & $65,17-91$ \\
\hline $\begin{array}{l}\text { PS at nivolumab initiation } \mathrm{n}(\%) \\
0-1 \\
\geq 2 \\
\text { Missing }\end{array}$ & $\begin{array}{l}204(67 \%) \\
69(23 \%) \\
30(10 \%)\end{array}$ \\
\hline $\begin{array}{l}\text { PS at first nivolumab evaluation } \mathrm{n}(\%) \\
0-1 \\
\geq 2 \\
\text { Missing }\end{array}$ & $\begin{array}{l}133(44 \%) \\
120(40 \%) \\
50(17 \%)\end{array}$ \\
\hline $\begin{array}{l}\text { Number of lines received before nivolumab } n \\
\text { (\%) } \\
\quad 0 \\
1 \\
\geq 2\end{array}$ & $\begin{array}{c}1(<1 \%) \\
120(40 \%) \\
182(60 \%)\end{array}$ \\
\hline $\begin{array}{l}\text { Metastatic sites at nivolumab initiation } \mathrm{n}(\%) \\
\text { Lung/pleura } \\
\text { CNS } \\
\text { Liver/adrenal glands } \\
\text { Bone }\end{array}$ & $\begin{array}{c}208(69 \%) \\
62(20 \%) \\
102(34 \%) \\
78(26 \%) \\
\end{array}$ \\
\hline Number of nivolumab injections (median, range) & $6,1-43$ \\
\hline $\begin{array}{l}\text { Radiation therapy } \mathrm{n}(\%) \\
\text { Yes } \\
\text { No }\end{array}$ & $\begin{array}{l}176(58 \%) \\
127(42 \%)\end{array}$ \\
\hline $\begin{array}{l}\text { Duration of treatment before nivolumab, months } \\
\text { (median, range) }\end{array}$ & $14(1-216)$ \\
\hline
\end{tabular}


Table 2: Comparison of the clinical and pathological characteristics in the two study groups

\begin{tabular}{|c|c|c|}
\hline Characteristics $(n=292)$ & $\begin{array}{l}\text { Progression at } \\
\leq 2 \text { injections } \\
(n=57,20 \%)\end{array}$ & $\begin{array}{l}\text { Progression after } \\
>2 \text { injections } \\
(\mathrm{n}=228,78 \%)\end{array}$ \\
\hline \multicolumn{3}{|l|}{ Sex $n(\%)$} \\
\hline Male & $39(68 \%)$ & $156(68 \%)$ \\
\hline Female & $18(32 \%)$ & $72(32 \%)$ \\
\hline \multicolumn{3}{|l|}{ Smoking history $\mathrm{n}(\%)$} \\
\hline Current or former & $51(89 \%)$ & 209 (92\%) \\
\hline Never & $6(11 \%)$ & $17(7 \%)$ \\
\hline Missing & $0(0 \%)$ & $2(1 \%)$ \\
\hline \multicolumn{3}{|l|}{ Histology on initial biopsy n (\%) } \\
\hline Adenocarcinoma & $34(60 \%)$ & $140(61 \%)$ \\
\hline Squamous cell carcinoma & $14(25 \%)$ & $69(30 \%)$ \\
\hline Other & $9(16 \%)$ & $19(8 \%)$ \\
\hline \multicolumn{3}{|l|}{ Mutational status $\mathrm{n}(\%)$} \\
\hline EGFR mutation & $1(2 \%)$ & $9(4 \%)$ \\
\hline KRAS mutation & $8(14 \%)$ & $42(18 \%)$ \\
\hline ALK translocation & $1(2 \%)$ & $1(<1 \%)$ \\
\hline Other & $4(7 \%)$ & $15(6 \%)$ \\
\hline Wild type & $44(76 \%)$ & $167(71 \%)$ \\
\hline $\begin{array}{l}\text { Age at diagnosis, years (median, } \\
\text { range) }\end{array}$ & $64,30-91$ & $62,35-80$ \\
\hline $\begin{array}{l}\text { Age at nivolumab initiation, years } \\
\text { (median, range) }\end{array}$ & $65,34-91$ & $64,36-80$ \\
\hline \multicolumn{3}{|l|}{ PS at nivolumab initiation $\mathrm{n}(\%)$} \\
\hline $0-1$ & $24(42 \%)$ & 167 (73\%) \\
\hline$\geq 2$ & $24(42 \%)$ & $43(19 \%)$ \\
\hline Missing & $9(16 \%)$ & $18(8 \%)$ \\
\hline \multicolumn{3}{|c|}{ PS at first nivolumab evaluation $n(\%)$} \\
\hline $0-1$ & $0(0 \%)$ & $124(54 \%)$ \\
\hline$\geq 2$ & $50(88 \%)$ & $61(27 \%)$ \\
\hline Missing & $7(12 \%)$ & $43(19 \%)$ \\
\hline \multicolumn{3}{|l|}{$\begin{array}{l}\text { Number of lines received before } \\
\text { nivolumab } \mathrm{n}(\%)\end{array}$} \\
\hline 1 & $20(35 \%)$ & $90(39 \%)$ \\
\hline$\geq 2$ & $37(65 \%)$ & $138(61 \%)$ \\
\hline \multicolumn{3}{|c|}{ Metastatic sites at Nivolumab initiation } \\
\hline Lung/pleura & 45 (79\%) & $155(68 \%)$ \\
\hline CNS & $14(25 \%)$ & $45(20 \%)$ \\
\hline Liver/ adrenal glands & $19(33 \%)$ & $78(35 \%)$ \\
\hline Bone & $22(39 \%)$ & $53(23 \%)$ \\
\hline \multicolumn{3}{|l|}{ Number of metastatic sites } \\
\hline$\geq 2$ & $21(37 \%)$ & $106(46 \%)$ \\
\hline$<2$ & $36(63 \%)$ & $122(54 \%)$ \\
\hline \multicolumn{3}{|l|}{ Radiation therapy n (\%) } \\
\hline Yes & 27 (47\%) & $137(60 \%)$ \\
\hline No & $30(53 \%)$ & $91(40 \%)$ \\
\hline
\end{tabular}




\begin{tabular}{|l|c|c|}
\hline $\begin{array}{l}\text { Number of nivolumab injections } \\
\text { (median, range) }\end{array}$ & $2,1-2$ & $8,3-43$ \\
\hline $\begin{array}{l}\text { Duration of treatment before } \\
\text { nivolumab, months (median, range) }\end{array}$ & $11,1-86$ & $14,1-151$ \\
\hline
\end{tabular}

Table 3: summary of the different studies evaluating HPD, early death and refractory disease

\begin{tabular}{|c|c|c|c|c|c|}
\hline Study & Champiat et al & Inoue et al & $\begin{array}{l}\text { Saada- } \\
\text { Bouzid et al }\end{array}$ & Ferrara et al & Current study \\
\hline $\begin{array}{l}\text { Definition } \\
\text { of HPD }\end{array}$ & $\begin{array}{l}\text { RECIST progression } \\
\text { at first evaluation and } \\
\geq \text { two-fold increase in } \\
\text { TGR between the } \\
\text { REF and the EXP } \\
\text { periods }\end{array}$ & $\begin{array}{l}\text { Death within } \\
\text { three months } \\
\text { of nivolumab } \\
\text { initiation }\end{array}$ & $\begin{array}{l}\text { TGK ratio } \\
\text { (ratio of the } \\
\text { slope of } \\
\text { tumour } \\
\text { growth } \\
\text { before } \\
\text { treatment } \\
\text { and the } \\
\text { slope of } \\
\text { tumour } \\
\text { growth on } \\
\text { treatment) } \geq 2\end{array}$ & $\begin{array}{l}\text { RECIST } \\
\text { version } \\
1.1 \text { progressive } \\
\text { disease on the } \\
\text { first CT scan } \\
\text { during } \\
\text { treatment and } \\
\Delta \text { TGR } \\
\text { exceeding } 50 \%\end{array}$ & $\begin{array}{l}\text { Patients } \\
\text { receiving less } \\
\text { than three } \\
\text { injections of } \\
\text { nivolumab }\end{array}$ \\
\hline $\begin{array}{l}\text { \% of } \\
\text { patients } \\
\text { experienci } \\
\text { ng HPD }\end{array}$ & $9 \%$ & $18.9 \%$ & $29 \%$ & $13.8 \%$ & $20 \%$ \\
\hline $\begin{array}{l}\text { Cancer } \\
\text { type }\end{array}$ & $\begin{array}{l}\text { Multiple (melanoma, } \\
\text { lung, renal, colorectal, } \\
\text { urothelial, lymphoma, } \\
\text { HCC, head and neck, } \\
\text { ovarian, breast, } \\
\text { glioblastoma, cervix, } \\
\text { cholangiocarcinoma, } \\
\text { endometrium, gastric, } \\
\text { oesophagus, thyroid, } \\
\text { uveal melanoma, } \\
\text { mesothelioma, } \\
\text { pancreas, parotid, } \\
\text { sarcoma) }\end{array}$ & $\begin{array}{l}\text { Advanced } \\
\text { NSCLC }\end{array}$ & $\begin{array}{l}\text { Recurrent } \\
\text { and or } \\
\text { metastatic } \\
\text { head and } \\
\text { neck } \\
\text { squamous } \\
\text { cell } \\
\text { carcinoma }\end{array}$ & $\begin{array}{l}\text { Advanced } \\
\text { NSCLC }\end{array}$ & $\begin{array}{l}\text { Advanced } \\
\text { NSCLC }\end{array}$ \\
\hline $\begin{array}{l}\text { Patients } \\
\text { (n) }\end{array}$ & $\begin{array}{l}\text { Patients enrolled in } \\
\text { phase I studies (131) }\end{array}$ & $\begin{array}{l}\text { All-comer } \\
\text { patients (201) }\end{array}$ & $\begin{array}{l}\text { Not detailed } \\
\text { (34) }\end{array}$ & $\begin{array}{l}\text { Not detailed } \\
(406)\end{array}$ & $\begin{array}{l}\text { All-comer } \\
\text { patients (292) }\end{array}$ \\
\hline Drugs & $\begin{array}{l}\text { Anti PD-1/PD-L1 } \\
\text { monoclonal antibodies }\end{array}$ & nivolumab & $\begin{array}{l}\text { Anti PD- } \\
\text { 1/PD-L1 } \\
\text { monoclonal } \\
\text { antibodies }\end{array}$ & $\begin{array}{l}\text { nivolumab, } \\
\text { pembrolizumab, } \\
\text { atezolizumab, } \\
\text { durvalumab }\end{array}$ & nivolumab \\
\hline
\end{tabular}




\begin{tabular}{|c|c|c|c|c|c|}
\hline $\begin{array}{l}\text { Factors } \\
\text { associated } \\
\text { with HPD }\end{array}$ & $\begin{array}{l}\text { Older age, lower rate } \\
\text { of new lesions at } \\
\text { progression }\end{array}$ & $\begin{array}{l}\mathrm{PS} \geq 2, \mathrm{CRP} \text { to } \\
\text { albumin } \\
\text { ratio }>0.3 \text {, } \\
\text { response to } \\
\text { prior } \\
\text { treatment }\end{array}$ & $\begin{array}{l}\text { Regional } \\
\text { recurrence }\end{array}$ & $\begin{array}{l}\text { More than } 2 \\
\text { metastatic sites } \\
\text { before PD- } \\
\text { 1/PD-L1 } \\
\text { inhibitors }\end{array}$ & $\begin{array}{l}\mathrm{PS} \geq 2, \text { Shorter } \\
\text { duration of } \\
\text { treatment } \\
\text { before } \\
\text { nivolumab }\end{array}$ \\
\hline
\end{tabular}

